Article

\title{
Islamic Studies in Australian Islamic Schools: Learner Voice
}

\author{
Mohamad Abdalla *, Dylan Chown and Nadeem Memon $\mathbb{D}$ \\ Centre for Islamic Thought and Education (CITE), Education Futures, University of South Australia, \\ Adelaide SA 5001, Australia; dylan.chown@unisa.edu.au (D.C.); Nadeem.Memon@unisa.edu.au (N.M.) \\ * Correspondence: mohamad.abdalla@unisa.edu.au
}

Received: 29 June 2020; Accepted: 29 July 2020; Published: 6 August 2020

\begin{abstract}
This paper provides insight into senior secondary learners' views on Islamic Studies (IS) in three large Australian Islamic schools. This study offers a 'dialogic alternative' of 'speaking with' rather than 'speaking for' learners in Islamic educational research, planning, and renewal within K-12 Islamic schools. The study privileges learners' voice and enables an insight to their experience with one of the most important features of Islamic schools-Islamic Studies. Using phenomenology as a methodological framework, learner voice was elicited through focus groups where 75 learners (years 10,11, and 12) provided information describing their experience with Islamic Studies. Thematic content analysis of the textual data suggests that learners' dissatisfaction far outweighs their satisfaction with Islamic Studies. The findings of this paper can benefit Islamic schools in Australia and other Western contexts.
\end{abstract}

Keywords: Islamic Studies; Australia; Islamic schools; renewal; student; learner; voice

\section{Introduction}

The focus of this paper is on Islamic Studies (IS) as experienced by Muslim learners in selected Australian Islamic schools, not on the broader topic of Islamic education-defined as "the system and process of preparing people [Muslims] for success in this life and the hereafter" (Al-Refai 2011). Typologically, Douglass and Shaikh (2004) argued that Islamic education includes "education of Muslims", "education for Muslims", and "education about Islam". This articles explores Islamic studies as "education for Muslims" because "Full-time Muslim [or Islamic] schools fill the category of education for Muslims, because they embrace a much broader enterprise than mosque lectures, after-school programs and weekend schools" (ibid., p. 8). Islamic Studies can be defined as a "syllabus for the study of Islam as a subject in the school timetable where pupils undertake a programmed study of the main Islamic subjects" (ibid., p. 29). These subjects can include the study of the Qur'an, Hadith, Sìrah (biography of Prophet Muhammad), basic Fiqh (jurisprudence), Tärīkh (history of Islam and Islamic civilisation), and Akhlāq (ethics). Specifically, we are interested in exploring learner voice vis-à-vis Islamic Studies in selected Australian Islamic schools.

\subsection{Islamic Schools: Growth and Reasons for Establishment}

The first non-government, independent Islamic schools were established in Sydney and Melbourne around 1983. This is relatively new compared to, say, schools established by the Anglican Church in NSW in the late 1700s (Buckingham 2010). Like other Australian government and non-government schools, Islamic schools are "required to meet public standards of educational and financial accountability, and comply with the legislative, regulatory and reporting requirements that apply to all schools ... [and] must meet the criteria established by the relevant state or territory government for registration as a school" (Independent Schools Council of Australia 2019). 
There has been a steady growth of Islamic schools in Australia, the USA, the UK, and Canada-each with their own unique vision, mission, and philosophy. Islamic schools' heterogeneity reflects the religious and cultural diversity of Muslims. Islamic schools reflect the "rich diversity of interpretation of what Islamic education is and can be" (Memon 2016). Therefore, while "Islamic schools do not adopt a single common purpose", some common aims appear to be high quality education and the achievement of a strong Muslim identity that will facilitate participation in society. Further, reasons for establishment include: to "instill (sic) religious and cultural values in students" (Shakeel 2018); parents' concern for their children's "identity and belonging" (McCreery et al. 2007); as protection against "racism" (Shah 2012); "strengthen[ing] the sense of Muslim identity while focusing on improving the quality of education" (ibid.); "the ethnic and religious socialization"; and to counter challenges faced in public schools, including "religious practice, dress code, sexual ethics, stereotypes and biases, Islamophobia, and curriculum-related challenges" (Ahmed 2016).

\subsection{IS in Islamic Schools}

Islamic Studies is not considered a Key Learning Area (KLA) in the Australian National Curriculum, which causes a host of challenges, including how to fit IS in an already cramped curriculum and school timetable. Therefore, Islamic schools typically allocate about $2 \mathrm{~h}$ weekly for IS, making it the faith appendment to a school, and treat it as a single subject devoid of depth and specialisations. Further, Islamic schools (like many other schools) are driven by academic performance and results, forcing them to give less value and attention to IS than other subjects or key learning areas (KLAs). This means IS classes can be cancelled on a whim to accommodate the 'other' subjects; classes can be cramped (in one of the schools under study IS class had 80 learners); IS resources are scarce; IS teachers are not provided with the same professional development as other teachers, all of which leads to disengagement and frustration. Additionally, given there is no standard or national Islamic Studies curriculum, each school tends to adopt their own curriculum, which is often made up of textbooks or imported curricula which are decontextualised. Commonly used and accessible, Islamic Studies curricula in English speaking countries are: IQRA' Islamic Studies curricula (origin, USA); Tasheel curriculum/textbook series (origin, South African); iSyllabus (origin, Scotland), and the I Love Islam textbook series (origin, USA).

Little is known about IS in Islamic schools. There is even less information on learners' voice and IS. In 2019, Ucan and Wright (2019) explored improvement of the pedagogy of Islamic religious education at a secondary Muslim girls' school in London with 30 students (aged 11) of two seventh grade classes and their religious education teacher. They found that using critical religious education, variation theory, and the learning study model in teaching Islam contributes to students' learning outcomes. The study solicited students" views "to identify the critical aspects in their understanding of the object of learning and to make use of this feedback to design the teaching-learning environment" (ibid., p. 208), but did not explore students' voice regarding IS per se. Using qualitative case study methods, Alaboudi's PhD dissertation explored what teacher (mostly Islamic Studies teachers) practices support successful student experiences in relation to positive identity development at three privately funded K-12 Islamic Schools in the U.S. (Alaboudi 2018). The study, however, did not explore learner voice and IS.

Memon has written extensively on Islamic schools and Islamic pedagogy but not on learner voice and IS (Memon 2019; Memon and Alhashmi 2018; Memon and Zaman 2016; McDonough et al. 2013; Memon 2011, 2012). Equally, Clauss et al. (2013) examined the nature and the growth of Islamic schools in the United States from the perspective of Muslim administrators, teachers, parents, and graduates, but not learner voice and IS. Al-Refai's (2011) comprehensive qualitative research includes seventy-six interviews (with teachers, pupils, parents, head teachers, governors, and community leaders), classroom observations, and document analysis. Al-Refai found that there is no "unified set of guidelines, agreed syllabus or curriculum framework for the teaching of Islamic Studies in all the six schools; and there is no philosophical statement for their Islamic Studies" (ibid., p. 229). Stakeholders in the six schools "noted the importance of modernising the curriculum in order to respond to the needs of pupils in 
British society", despite the fact that "parents, community leaders and educators often have difficulty in considering the British context when designing Islamic Studies curricula" (ibid., p. 6). Importantly, the study found that-at times-school governors, scholars, community leaders, teachers, and heads of departments are involved in the evaluation of the Islamic Studies curricula, but not the learners. Again, this study did not examine learner voice and IS.

A larger study by Hussain and Read (2015) drew on extensive qualitative data collected over 20 months at three Islamic schools in the US (North Carolina) and England (Oxfordshire and Lancashire) to explore implications for integration and social cohesion. In-depth interviews were conducted with 15 mothers and 5 school administrators and teachers; 12 focus groups with students from different grade or year levels; and in-depth interviews were conducted with 20 Muslim students who were currently enrolled in a public university, half of whom had attended an Islamic school and half of whom had not. The study found that Islamic schools can facilitate the participation of Muslims in mainstream institutions by equipping them with the cultural capital needed to navigate non-Muslim arenas, but that "does not necessarily translate into greater levels of religiosity among Muslim youth; in some cases it even turned them away from the religion." The study, however, did not examine learner voice and IS.

Diallo and Kerrilee (2016) examined the role and importance of Islamic studies and faith in community Islamic schools in Adelaide and Darwin, Australia, where definition of Islamic Studies is confined to "studying the Quran (developing Qur'anic literacy) as well as learning the Arabic language." Of all the 61 participants, $29.56 \%$ (almost 18) were Muslim students aged 15-18. The study does not present the views of these students as a distinct voice, rather it provides general conclusions based on the views of all 61 participants. Importantly, the study demonstrates that the participants' have a strong attachment to their Islamic studies; the importance of learning Arabic because it is associated with accessing Quranic knowledge; the insufficient number of hours allocated for Islamic Studies classes; and the importance of Islamic Studies in developing and maintaining students' Islamic identities. More recently, Abdalla (2018) examined the views of 44 participants (including 10 IS coordinators, 15 IS teachers and 19 senior learners (grades 10-12) of one Australian Islamic school in Victoria. The study found that students desire to study IS, show reverence for IS teachers, and appreciate the fundamental basics of Islam taught at the school. However, they complained that Islamic Studies was "repetitive", "boring", "irrelevant", "out-of-context", and "biased". Further, students expressed "frustration because they 'expect deeper understandings' of Islam through inquiry as to the 'why', as well as the reasoning behind Islamic principles on a variety of issues relevant to their lives." Students also argued that IS does not provide "depth in real life issues", or to learn as Muslims "how to live in society" (to become functional Muslims), and to gain the knowledge and skills to "apply what is being learnt." The study suggested that IS needs to "accommodate the reality" of students' needs, have "high standards and expectations that are challenging yet realistic" and be established on "a strong evidence base" (ibid., p. 274). Given the limited data of the study, a key recommendation was further research in this area.

\subsection{Why is Learner Voice Important?}

An Islamic episteme may add nuance to the importance of learner voice from an Islamic perspective, but literature is devoid of this discussion and it is not the focus of the article. However, a cursory examination of primary Islamic texts (Qur'an and Hadith) reveals the importance of learners' voice (and young people generally), and the following examples suffice. Chapter 18 of the Qur'an, "The Cave" (al-Kahf), is thus named to commemorate the bravery and valour of a group of young people who spoke up against a tyrannical ruler. The act of expressing young people's voice is eloquently captured at the outset of the sura (verses 13-14) thus:

[Prophet], We shall tell you their story as it really was. They were young men who believed in their Lord, and We gave them more and more guidance. We gave strength to their hearts when they stood up and said, 'Our Lord is the Lord of the heavens and earth. We shall never call upon any god other than Him, for that would be an outrageous thing to do. 
(Abdel Haleem 2016)

Further, the following hadith (sayings, actions and tacit approvals of Prophet Muhammad) demonstrate respect for young learners' voice by Prophet Muhammad himself, in the presence of elders (sahaba):

Narrated Sahl bin Sad: God's Messenger was offered something to drink. He drank of it while on his right was a young boy and on his left were some elders. He said to the boy, "May I give these elders first?" The boy said, "By God, O God's Messenger! I will not give up my share from you to somebody else." Accordingly, God's Messenger gave the drink to the young boy before the elders.

(Sahih al-Bukhari 2016, Book 74 Hadith 46)

Islam strongly advocates respect for elders, but the Prophet's practice (sunnah) is to always start any good practice such as eating and drinking from the right hand. Though wanting to pay respect to the elders by giving them the drink, he sought the permission of the young man sitting on him right. In doing so, the Prophet recognised and respected the young man's voice, which is a key feature of Prophetic pedagogy.

A fixed definition of 'student voice' is difficult to identify in literature, and encompasses positive and negative aspects in educational research and practice (Cook-Sather 2006). However, learner voice research reflects a move from "research on students to research with students" (Woodward et al. 2017). This is a "dialogic alternative" of "speaking with rather than speaking for" students in educational "research, planning, and reform" (Fielding 2004). The positive aspects of this include: a cultural shift that "alter[s] dominant power imbalances between adults and young people," recognises the rights of young people as citizens and "active participants" in school, and engenders feelings of respect among students, leading to increased participation and communication between students and teachers; and the necessity for adults to "listen closely" to students, which can yield positive and transformative effects (ibid.,). The negative aspects include the risk of students' voices being treated as a 'monolithic' entity, which ignores the different needs and perspectives within the student group, the potential dismissal of students as 'children', the use of student voice for the sake of legitimising 'pre-determined' reform, and the potential use of student voice against students and teachers (in terms of criticism) (ibid., pp. 367-69).

Learner voice is also important for genuine school renewal efforts. Rather than relying upon 'result-centric' or 'deficit-oriented' quantitative evidence, educational renewal must include learners' voices, and value their cultural [and religious] backgrounds in order to "[build] upon the unique strengths they bring to school" (Friend and Caruthers 2015). Learner voice is also important to improve teaching practice (Messiou and Ainscow 2015), because collaboration among educators is as important as including learner voice for stimulating change in individual and school-wide practice. Through engaging with learners' voice and discussing their experiences with colleagues, educators often changed "minor aspects of their practice that were seen to lead to improvements in learning outcomes", even leading to some educators including learners in lesson-planning and co-design of curriculum - as well as an increased level of interest and participation from students involved by their teachers (ibid., p. 252). Including learner voice can also help shift attention from assessment to something more fundamentally important to them-the importance of learning with respect to their futures (Bourke and Loveridge 2016). It can also positively affect student well-being (Halliday et al. 2019). These benefits include increase personal competency in terms of student engagement, self-efficacy and research skills, student autonomy, engagement with their own school, and increased student satisfaction "in being involved in school affairs, and being able to help the school" (ibid., pp. 19-20).

In the case of IS in Islamic schools, learner voice is almost totally absent and if schools are to renew IS in ways that are reflective of learners' needs and aspirations, then exploring their voice and including it is timely, necessary, and important. 


\section{Methodology}

This research utilised a qualitative, phenomenological methodology that considers "the meanings and interpretation of social phenomena and social processes in the particular contexts in which they occur" (Sumner 2006), aims to "capture the essence of the experience" and gain an understanding of "how the participants make sense of their everyday world", and "attempts to understand the essence of a phenomenon from the perspective of participants who have experienced it" (Eddles-Hirsch 2015). In attempting to provide rich and detailed description of the phenomenon being studied, phenomenology allows us to provide descriptions of 'how' learners ('the participants') experienced Islamic Studies rather than "any preconceived perception the researcher may have of the phenomenon being studied." This allows us ('the researchers') to "listen and record the participants' description of an experience in an open and naïve manner" (ibid., p. 252). This is followed by an "imaginative variation process" that allows us to "uncover structural themes sourced from these textual descriptions", helping in developing an understanding of the "essence of the phenomenon being researched" that is not exhaustive but represent a "perspective at a particular time and place" (ibid.).

\subsection{This Study}

The literature review demonstrated that most research in Islamic schools has been conducted from the outsider ('academics') not the insider ('learner') perspectives. This study aims to describe the learners' experience from their own perspective and not that of the outsider. For this reason, a phenomenological approach was selected for this study. Through the learners' rich, in-depth description of their experience with Islamic Studies ('lifeworld') and the researchers' use of phenomenology, an understanding was achieved on how senior Australian Muslim learners experience Islamic Studies in an Islamic school setting.

The research questions that guided this study:

1. How do senior learners perceive and experience the strengths of Islamic Studies at their Islamic school?

2. How do senior learners perceive and experience the challenges of Islamic Studies at their Islamic school?

\subsection{The School Sites}

Students were selected from three large Islamic schools: school A is based in New South Wales; School B is based in Queensland; and School C has campuses in Western and South Australia. These schools are among the oldest and largest Australian Islamic schools, with large student populations. They are co-educational, K-12 schools and are similar in many ways. Table 1 provides an overview of the demographic context of these schools.

Table 1. Context overview (2019). Source: https://www.myschool.edu.au/.

\begin{tabular}{cccc}
\hline Demographic Context & School A & School B & $\begin{array}{c}\text { School C (with Campuses in } \\
\text { Western Australia and South } \\
\text { Australia) }\end{array}$ \\
\hline School sector & Non-government & Non-government & Non-government \\
\hline School type & $\begin{array}{c}\text { Combined (boys and } \\
\text { girls) }\end{array}$ & Combined & Combined \\
\hline Year range & Prep-12 & K-12 & PP-12 \\
\hline Location & Major cities & Major cities & Major cities \\
\hline
\end{tabular}


Table 1. Cont.

\begin{tabular}{cccc}
\hline Demographic Context & School A & School B & $\begin{array}{c}\text { School C (with Campuses in } \\
\text { Western Australia and South } \\
\text { Australia) }\end{array}$ \\
\hline $\begin{array}{c}\text { Enrolments } \\
\text { Index of Community } \\
\begin{array}{c}\text { Socio-Educational Advantage } \\
\text { (ICSEA) }\end{array}\end{array}$ & 1165 & 1851 & 3169 \\
\hline $\begin{array}{c}\text { Language background other } \\
\text { than English }\end{array}$ & $95 \%$ & 1089 & 993 \\
\hline $\begin{array}{c}\text { Indigenous (a person of } \\
\text { Aboriginal or Torres Strait } \\
\text { Islander descent) students }\end{array}$ & $0 \%$ & $97 \%$ & $98 \%$ \\
\hline Boys & $46 \%$ & $0 \%$ & $0 \%$ \\
\hline Girls & $54 \%$ & $46 \%$ & $50 \%$ \\
\hline
\end{tabular}

As evident in Table 1, the only major difference between the three schools is the number of enrolments, where School $C$ has the largest number because they have multiple campuses. The following table (Table 2) provides a summary of important features related to IS at the schools.

Table 2. Islamic Studies context overview.

\begin{tabular}{cccc}
\hline IS Context & School A & School B & School C (with 4 Campuses) \\
\hline Number of IS classes per week & 1 & 1 & 1 \\
Number of hours per week & $2 \mathrm{hrs}$ & $2 \mathrm{hrs}$ & 2hrs (per class) \\
Number of IS male educators & 3 & 1 & 25 (in 4 campuses) \\
Number of IS female educators & 0 & 1 & 13 (in 4 campuses) \\
Class size & $30-40$ & $40-80$ & $30-40$ \\
Textbook & Yes & Yes & Yes \\
\hline
\end{tabular}

\subsection{Participants}

Consistent with phenomenological research, participants were selected based on their experience with Islamic Studies ('the phenomenon') that is being researched and were willing to describe it in a tape-recorded interview (Eddles-Hirsch 2015, p. 254). Although phenomenological samples do not need to be large in number, they require enough participants to offer different perspectives of the phenomenon being studied. For this study, 75 senior students who have experienced Islamic Studies participated in this research, 40 senior boys and 35 senior girls (see Table 3). A purposive sampling method was used to identify and recruit focus group participants from years 10, 11, and 12 only, who can "provide the greatest insight" to the investigation of the research question (Devers and Frankel 2000; as cited in Etikan et al. 2016). Eight focus groups (8-10 in each focus group) were conducted, and discussions were audio recorded. Participants provided diversity according to the following criteria: year levels involved in Islamic Studies (Years 10, 11, and 12); gender balance (male and female); being from diverse ethnic backgrounds and having studied at the school for several years. Schools were informed that the student population must consist of a cross section of these criteria and, based on evidence collected during the data collection and trust developed with school leaders, the selection of student participants was successful.

Table 3. Study participants.

\begin{tabular}{cccc}
\hline Participants & School A & School B & School C \\
\hline Students & 20 & 15 & 40 \\
Male & 10 & 8 & 20 \\
Female & 10 & 7 & 20 \\
Year & 10,11 , and 12 & 11 and 12 & 10 and 11 \\
\hline
\end{tabular}




\subsection{Data Collection}

In this phenomenological study, data were collected from in-depth interviews, which provides rich participants' descriptions of the phenomenon under investigation. Over two years, data were collected from School A in early 2019, School B in 2018, and School C late 2019. There was an already established relationship with School A and C, which made it easier to access participants. The relationship with School B was gradually built mainly through the intervention of one of the senior Islamic Studies coordinators. Initial discussions with school leaders (principals, deputy principals, some board members) were conducted via email and in person. This was followed up with visits to discuss the project with learners, educators, coordinators, and parents (School B did not give access to parents throughout the process). This process enhanced the trust that already existed between the research team and the schools.

Given the focus on learner voice, enough time was spent at the beginning of every focus group to explain the nature of the project, why it was being conducted, expected benefits from participating in the research, and how the data would be used and any risks involved. Time was also allocated to respond to any questions or concerns. Participants were also provided with information sheets and consent forms. All schools and participants were informed that their participation was voluntary and that they could withdraw from the research at any time without fear of any risk to them or their schools. Researchers' contact details were also made available in case students needed further information or wished to provide feedback on the project. Students were informed that their identities would be kept confidential when the data were analysed and shared in the form of research publications. We allocated $1 \mathrm{~h}$ per focus group knowing that the first 10-15 min would be used to explain the project and answer any questions.

\subsection{Organising, Analysing, and Synthesising Data}

First, data were transcribed verbatim and when reading the participants' transcripts, we engaged in the phenomenological process of 'epoche', also known as "bracketing whereby the researcher purposefully sets aside any preconceived knowledge or everyday beliefs he or she regards might be used to explain the phenomena being investigated" (Eddles-Hirsch 2015, p. 251). Reading each transcript, we were involved in the phenomenological reduction process of horizontalization of the data (ibid., p. 255) to look for themes in their description of Islamic Studies. Meanwhile, we were receptive to every statement of every participant's experience and giving each comment equal value (Eddles-Hirsch 2015). Themes that addressed the research questions were cut out of the transcript and pasted in a table in a separate document. This ensured that student voice was preserved and not altered (Swain et al. 2018). We then reviewed the themes listed for each participant to ensure that there were no overlapping or repetitive statements. We then gathered core themes from all participants and formed composite textual descriptions for each of the three schools. We then amalgamated the composite textual descriptions representing the essences of the phenomenon under study from the perspective of the participant.

\section{Findings}

Overall, thematic content analysis of the data revealed multiple themes, each of which will be explored with learners' insights about Islamic Studies. These themes can be broadly categorised under "strengths" and "challenges" of Islamic Studies. In all schools, participants were delighted that they had been included in this research. They all said this was the first time anyone had asked them about their views. Interestingly, when discussing their views of the strengths of Islamic Studies, participants were brief and less enthusiastic than when discussing the challenges. 


\subsection{Category 1: Strengths}

\subsubsection{Theme 1: Importance of Islamic Studies and its Role in Instilling Fundamental Teachings}

All participants expressed a consensus as to the importance of Islamic Studies, and acknowledged the role of Islamic Studies in instilling and reinforcing ritual practice, and its role in contributing to the rhythm of the Muslim way of life in school life (in important matters such as fasting in the month of Ramadan, celebration of Eid, and the five-times-daily prayers. The comments reflecting this are best represented by a male student:

I am just going to say that Islamic Studies helps establish the principles of Islam to like the five pillars of Islam-six pillars of faith-they help us establish that and make sure it doesn't waiver us. We have a clear understanding of what Islam is and why we actually practice Islam.

Elaborating on this, some learners stated that basic teachings of Islam include learning about Islamic etiquette and personal hygiene at high school, as expressed by this participant:

Yeah, like [in primary school we learnt] the prayer and how to do specific things, and like what follows and stuff like that. And then when we get older, for example like this year, we're doing in Year 12, doing a lot of stuff with like how to keep clean and then learning ... the etiquettes with your wife and stuff like that.

\subsubsection{Theme 2: Reverence and Admiration for IS Educators}

Learners have also expressed their admiration for many of their Islamic Studies teachers and recognised their religious knowledge and experience. For example, one student said, "you can just go up to them immediately, it is not an issue ... there is that openness where you can go to them and ask a question." In every focus group and school, learner participants were adept at identifying the Islamic Studies educators who were approachable, who understood their professional role as extending beyond concerns of the classroom-they were also quick to point out that this stand-out educator was usually the exception. Few learners felt that they could express themselves freely in the IS classroom, "So, you're able to engage in a discussion very freely, even if your point of view is not necessarily correct, you're able to have that."

\subsubsection{Theme 3: Importance of Female Educators}

School A had no female IS educators. School B had only 1 female Islamic Studies teacher, and School $C$ had 13 female teachers across 4 campuses. Female participants valued having female educators because they felt comfortable speaking about female-related issues as this participant observed, " ... you can speak about any issue that you have to her, and it can be private if you do not want to speak about it in front of everyone." Other participants identified opportunities and educators in Islamic Studies who engaged in dialogical pedagogy, who considered the lifeworlds of learners, who valued the issues most relevant to learners and their lives. Other female learners recognised that the female teacher equips them with knowledge that is useful, such as youth identity: " . . currently we're talking about the identity of, I think the Muslim identity, and what you classify yourself as and problems with the outside world and all that, so." Some other female students were equally pleased with the female teacher because, "Instead of just speaking she uses multimedia to portray what she is trying to say. So, it can become more engaging to the class."

\subsubsection{Theme 4: Conspicuous Absence of IS Homework}

Many participants spoke of a plan for memorisation practice at home (surahs, hadith and duas) — not viewed by learners as homework (a positive). Participants were pleased not to have additional stress in their homework loads (although all schools adopted a strong homework emphasis across the school). This may have, subliminally, fed into the notion that Islamic Studies is not 
commensurate to, or as important as, other learning areas-not because homework should be viewed as essential for high quality Islamic Studies, rather its conspicuous absence in homework-heavy school culture. Students expressed this sentiment thus: "We do not have to-with Islamic Studies, it is not as if-we do not do too much-like it is not too much of a burden on us in terms of the workload, so we don't usually get homework but we will probably have like assessment."

Participants across all schools reported a heavy testing approach to assessment, but in Schools B and $C$ participants spoke positively about a recent shift to additional modes/mediums of assessment including PowerPoint presentations, multi-modal presentations or posters, "And, for our exams, they're not just written exams sometimes we have PowerPoint, sometimes speeches, and there was also one you had to create a poster or something, so it's engaging as well." The same participants described these assessments as superficial, in that they generally involved shifting pre-packed context (usually from the text) to a poster or PowerPoint presentation uncritically-learners viewed this as positive step, albeit quite a superficial form of assessment 'of' learning.

\subsection{Category 2: Challenges}

3.2.1. Theme 1: Lack of Lesson Plans and Coherence across Unit Planning (Topics and Themes not Aligned, Connected or Building Upon One Another)

Learners from the three schools repeatedly expressed concerns about the lack of lesson plans and coherence across unit planning for Islamic Studies. This was best captured in this student's voice:

I think it would benefit more especially in Year 11 and 12 to have some schedule to our lessons because- but it's-I guess it's hard because we don't have much [of] that time as well, and everyone's really preoccupied so that's probably ... it would benefit more if we went into class with a discussion in mind or something like that. But we go in; sometimes the topics can be different because we don't have Islamic Studies that often as well.

Another learner said, “So, I feel our lessons aren't organised that we got, [we] start a topic or we might not finish it, or we might start moving onto something else because the timings of our lessons are ... there is quite a gap between lessons as well." Another stated, "... sometimes things are left unfinished or we just start a new topic and I feel like we walk into class, we do not know what is exactly going on. So sometimes if we know what we are talking about, we can prepare questions and discussions and just engage naturally, so."

\subsubsection{Theme 2: Textbook Focused and History-Centric}

All the schools under study relied heavily on imported textbooks, which was viewed negatively by learners, " ... the students, they will forget their book half the time and stuff like that. So, it's not a strong enough structure, so at the end of the day it just, at the end of the year nothing gets accomplished, yeah." This leads to disengagement with IS, "Yeah, it is like it's not given enough attention compared to a subject like maths or something."

Many of the senior learners strongly argued that Islamic Studies is textbook-heavy and impractical:

So, this is a really major problem that's in this school-like the practical part of Islamic Studies. Like it is usually mainly textbook work, but we are not actually doing interactive stuff like worksheets or like even the practical way of learning-like getting the students [to] actually do stuff and not just textbook then read, textbook then read.

Another repeated complaint by learners is that Islamic Studies is history-centric, disconnected from their daily lives, or decontextualised. This was summed up thus, "So, basically, we learn Qur'an and our textbook is mostly history, it's not about Islamic daily lives, it's more about the history of Islam." Another said, "For us the only thing we can really [learn] is the Qur'an ... we do not actually learn anything else that we can practice because it is more history." The majority of students expressed dislike 
for the textbook approach to teaching Islamic Studies, and most students spoke of problems they have identified with the textbooks: spelling, grammar, and punctuation errors, the fact that the text is not organised or structured (e.g., to locate terms or definitions requires trawling through entire book); hard to understand; the text contains mostly the same content every year with slight additions or extra detail.

In one of the campuses at School C, learner participants who had an Islamic Studies teacher who was enrolled in a Master of Teaching program (towards teacher registration in addition to his subject discipline qualifications in Islamic Studies) had moved away from the textbook-led approach, and adopted more issue-based, dialogical pedagogy. Participants expressed a very positive experience of this shift.

\subsubsection{Theme 3: Absence of an Engaging Pedagogy}

The absence of well-structured unit and lesson planning whereby the unit focus and aims are apparent to learners is coupled with an absence of an engaging pedagogy, leading to student disengagement: "Yeah a lot of students just don't interact with the lesson because they are not finding it engaging, so if there is a more engaging method of actually learning which can get all the students to participate." This perspective was pervasive among most learners.

\subsubsection{Theme 4: Does not Teach Social Skills}

Some learners argued that while Islamic Studies focuses on the main principles of Islam, it does not teach them how to be functional in society through social skills, as expressed by this student, " ... I feel like we are lacking in like social skills, like what it is to be a Muslim in the actual community-how it is, like are we supposed to give da'wa [inviting to Islam], how are we supposed to treat each other. They just barely touch on that and focus more on the principles."

\subsubsection{Theme 5: School does not Take IS Seriously}

A common theme that emerged is learners' belief that their school does not take Islamic Studies seriously: "I feel like as we enter high school in the school, not as big of an emphasis is put on Islamic Studies ... it is more of just an afterthought." In fact, they argued that Islamic Studies is not given the same importance, and is not taken seriously, by their school's 'leadership' and 'administration'. They also said that the schools' leadership do not "build up the respect for our Islamic Studies teachers as much as they should", and that "the students have been conditioned to not really show the respect that they [Islamic Studies teachers] deserve". One of the main reasons for this prevailing sentiment is that Islamic Studies is considered less important by the schools than other key learning areas:

I think the reason why students are not able to express importance, or the teachers are not able to get through to the students [is] because the other subjects, other subject teachers express a lot of importance for mathematics and science. They always tell you, "This is important, this always goes first." So you're not able to have, you honestly, you don't have time because you should always have time, but in your brain you don't, you don't want to do it because you have more important things to focus on [other than Islamic Studies].

Another learner stated, "Yeah, in a way. I think Islamic Studies everyone is like oh, we have Islamic Studies now, it's not that big of a deal"; another student said, "Nobody realises the whole point they sent you to an Islamic school is for that subject [Islamic Studies]. If your parents ... did not want you being taught Islamic Studies and Arabic, they would not have sent you here, but yeah, that is the subject that [gets] paid the least attention to." Learners also perceive that Islamic Studies was not taken seriously by the schools' leadership:

I don't think they're taking it seriously, because if you go into other classes, you still see students without books, students sleeping. If they were taking it seriously, everyone would be awake, engaged in the learning, with their book out and everything. Nah, I don't think they take it seriously. 


\subsubsection{Theme 6: Insufficient Hours for IS}

The feeling that Islamic Studies is not as important as other subjects is exacerbated by the fact there are often only one or two hours for Islamic Studies per week (at all schools). Therefore, some participants argued for more Islamic Studies classes, even "afternoon or morning classes". Others objected because "it would be hard for the school because there are so many morning classes and afterschool classes for just the normal [emphasis added] subjects." Another learner said that extra classes would not be useful because, "[Students] are not motivated to study Islamic Studies, they just see it as a bludge [Australian slang for lazy] lesson. So, even if these classes are put on, there will be only I feel a small amount of girls that will actually feel motivated to go every single day or whenever they're on, so."

\subsubsection{Theme 7: Repetitive}

Many participants contended that Islamic Studies "gets repetitive", and "sometimes you hear the same thing every two years" or, "Yeah, it is redundant." When asked about what would be practical and non-repetitive, they said they wanted contemporary issues, "Like LGBT [issues] and stuff like that, transgender people; I guess if we had learned about from an Islamic perspective we wouldn't be worrying as much and asking the Imams." This comment occurred at a time when many countries including Australia had moved to marriage equality and a sudden and persuasive increase in debates and discourse around LGBT issues in contemporary culture, something learners reported was largely ignored in Islamic Studies. Other examples of practical, non-repetitive examples were captured by this student:

... when you go outside into western society there's so many people saying, are talking about feminism and how it's completely opposite to what Islam teaches us. But if in Islamic school they could teach us the beauty in it then when we go out into society and stuff like that, we can explain to people why we do it and it's beautiful to us, and our outlooks won't change and stuff like that, so I think that's important.

\subsubsection{Theme 8: Does not Prepare Students for the 'World Outside'}

When asked "do you feel Islamic Studies prepares you for the world outside?" many participants responded emphatically, "No"; rather they felt that, "You have to prepare yourself, you have to ask the questions". In fact, they contended that the questions they prompt are the most interesting part of Islamic Studies, as this learner argued, "I am pretty sure everyone can agree with this, that a question is more interesting than what we are actually being taught in the textbook."

\subsubsection{Theme 9: Lacks Critical Thinking}

The participants agreed that Islamic Studies does not allow for "critical" thinking and/or discussion because it is 'set in stone', as one student stated:

I think that our discussion, sometimes it is hard to get into discussions with the classroom. It may seem unapproachable to display a viewpoint and, in that sense, we cannot get into that mode of critically thinking and discussing from what we think. People will not speak up, or their views, or maybe they are just afraid that they think they are going to be told that they are wrong or something when it is more, it is more a discussion.

\subsubsection{Theme 10: Class Size is Problematic}

Class size was another problem particularly at Schools A and B. Participants from School B were highly critical of the large class size (40-50 and sometimes 80 students in one class). They explained that Islamic Studies was the only 'free period' and so the school "combines all students in one class", making it very difficult for the teacher and students. Consequently, the participant explained, "For the 
first 15-20 min of the class she's [teacher] trying to gather the class", "You hear her on the loudspeaker", and "she'll be very angry because no one knows where to go." Senior learners from School A made a similar complaint, "We also have less [Islamic Studies] classes, plus Islamic class is generally bigger than all your other classes." They also said that large classes lead to "less attention" and "less concentration". Few other learners disagreed and argued that a larger class allows for diversity, especially in terms of the types of questions asked.

\subsubsection{Theme 11: Lacks Adequate Resources}

In all the three schools, learners argued there is lack of resources, or "resources that are not as advanced as you would have, say, for biology or physics." When asked what score they would give Islamic Studies resources, they said 2 or 4 out of 10 . They lamented the fact that other subjects are better resourced, including in the library, "But the shelves for Islamic, dedicated to Islamic Studies and Qur'an are ... they'll be on the side where not many people are able to see them, or they're not able to actually know that they're there."

\subsubsection{Theme 12: Biased and Contradictory}

With few exceptions, most participants were concerned that Islamic Studies was biased and that they did not study, or discuss, alternate scholarly viewpoints. One participant said, "I was just thinking there's a lot of books by different authors that could, that, they have lots of differing views I guess, and that's if we could discuss what about ... its learned people say." Another added, "Different viewpoints and stuff and stories, and there is a lot of really good books that discuss things in different lights. And, if we had more of those books, not only textbooks but its actual, things written by people." This viewpoint was emphasised further: "And, sometimes when you ask a question to an Imam [often an Islamic Studies educator], their school of thought is different to yours or they will just give you an answer according to their school of thought and ... they will give you a one-sided perspective, for example." They also complained about contradictions among Islamic Studies teachers, "Sometimes the Imams, they contradict each other, and they do not give you advice on which verdict to follow." Another added, "Which is understandable because there are controversial topics and people have deviations in opinion, but you don't know what to follow; you can bring it up to Imam that another Imam had a different opinion, but he won't-because it's wrong to put someone else's opinion down, so they don't really tell you which one to follow." Moreover, "They do not give you the conditions to follow this, or the conditions to follow that. It is really vague."

\section{Discussion}

In this research, we wanted to move from research on learners to research with learners, and to provide a 'dialogic alternative' of 'speaking with rather than speaking for' learners regarding IS. Accordingly, the insight provided by learners has been rich and insightful. Learners clearly stated that IS assisted them in learning the basic fundamentals of their faith, and that they valued their IS teachers, especially female teachers in girls' classrooms. Overall, however, the findings demonstrate that learners' dissatisfaction outweighs their satisfaction with IS at three Australian Islamic schools. Some of our findings affirm Abdalla's findings that learners have reverence for IS teachers and appreciate the fundamental basics of Islam they learn, but complain that Islamic Studies in their particular school contexts is "repetitive", "boring", "irrelevant", "out-of-context", and "biased" (Abdalla 2018). It also affirms Diallo and Kerrilee's (2016) findings that not enough hours are given to IS. Learners' complaints that IS lacks structure and coherency align with Al-Refai's research with six British Islamic schools that found there is no "unified set of guidelines, agreed syllabus or curriculum framework for the teaching of Islamic Studies in all the six schools; and there is no philosophical statement for their Islamic Studies" (Al-Refai 2011). This research has uncovered other themes not discussed elsewhere. From the learners' own perspectives, Islamic Studies is: given minimal importance by their particular schools compared to other subjects or key learning areas; has unacceptable class sizes; has inadequate 
resources; has limited planning across the school; heavily relies on decontextualised textbooks that are history-centric; does not prepare students for the 'world outside'; lacks critical thinking; does not teach social skills, and is not pedagogically engaging.

These are significant findings that require further investigation. For example, is there a link between learners' dissatisfaction with IS and the absence of overarching aims and objectives for Islamic Studies? Does the lack of resources, insufficient number of hours, and large classes tell us anything about school leaders' mindset regarding the place and value of IS? Is there a link between students' dissatisfaction with IS and Hussain and Read's (2015) finding that the cultural capital provided by Islamic schools "does not necessarily translate into greater levels of religiosity among Muslim youth; in some cases it even turned them away from the religion"? Should Islamic schools reconceptualise and think carefully about the place of Islamic Studies in Islamic schools and how it might be structured in the best interests of learners? Is it possible that an undeveloped faith-based Islamic school model has had an impact on Islamic Studies? Furthermore, what does Islamic Studies look and feel like in Islamic schools who have made it a priority and do indeed rely on learner voice?

A faith-based school is one that manifests a faith-based model that shapes the vision, philosophy, and aims of education. Islamic Studies is done a great disservice when it is viewed as the faith appendment to a school or treated as a single subject devoid of depth and specialisations. We contend that a fundamental reason for some learners' dissatisfaction with Islamic Studies is because it is treated as a strand of a single subject (i.e., Islamic Studies), rather than separate disciplines or subjects of specialisations. Islamic Studies is a broad banner that includes the traditional or classical disciplines of Fiqh, 'Aqāid, Akhlāqh, Tarikh, and Sirrah. It is counterintuitive to suggest that these can be treated as a single strand. This can be likened to the example of Humanities and Social Sciences (HaSS) in the Australian Curriculum, which is inclusive of History, Geography, Civics and Citizenship, Economics and Business. Each of these disciplines is treated as a separate specialisation, and HaSS has a larger time allocation and more resources than Islamic Studies. This is not to downplay the constant time pressure in relation to an already compacted curriculum and the fact that schools must make difficult decisions.

We know from Al-Refai's (2011) study with six British Islamic Schools, that school governors, scholars, community leaders, teachers, and heads of departments are involved in the evaluation of the Islamic Studies curricula, but not the learners. Our findings gave a voice to the learner, any future development of IS curricula must include this voice. Learners must be the co-designers of IS curricula. This can help improve teaching practice (Messiou and Ainscow 2015), because collaboration among educators is as important as including learner voice for stimulating change in individual and school-wide practice. Including learner voice can also help shift Islamic schools' attention from assessment and academic results to something more fundamentally important to them: the importance of learning, with respect to their futures (Bourke and Loveridge 2016).

\section{Conclusions}

Young Muslims are faced with twenty-first century challenges-with its complex environmental, social, political, and economic pressures. This requires a deeper understanding of Islam that goes beyond decontextualised textbooks, repetition of low-level knowledge that has been described by students in this study as boring, not-engaging, not taken seriously by schools, unstructured, and under-resourced. In this study, students felt deprived of the opportunity to develop skills and more in-depth Islamic knowledge as they progress through the years. Instead, students complained of repetition of basic knowledge from primary through to secondary school, leading to a perceived sense of stagnation in their study of Islam. The purpose of this study was to privilege learners' voice and give them the opportunity to tell us about their experiences with Islamic Studies in three Australian Islamic schools. Listening to their voice can help Islamic schools respond appropriately to their aspirations and needs. Although our findings provide us with a comprehensive understanding of Islamic Studies from the learners' perspectives in three Australian Islamic school, it is not generalisable. We are confident that there are also 'stories of hope' of many Islamic schools globally who take learner voice seriously and 
prioritise Islamic Studies in ways that likely challenge the findings of this study. However, in the absence of extensive empirical research of Islamic Studies in Islamic schools, this study provides critical insights that are important for the field. Further research is required in other Australian Islamic schools and in contexts internationally, such as the USA, the UK, Canada, and elsewhere.

Author Contributions: M.A. and D.C. collected the data. Mohamad Abdalla wrote the first draft of the article. D.C. and N.M. helped refine the literature review, methodology and findings, and contributed to the final draft of the discussion and conclusion. All authors have read and agreed to the published version of the manuscript.

Funding: This research did not receive external funding.

Conflicts of Interest: The authors declare no conflict of interest.

\section{References}

Abdalla, Mohamad. 2018. Islamic studies in Islamic schools: Evidence-based renewal. In Islamic Schooling in the West Pathways to Renewal. Edited by Mohamad Abdalla, Dylan Chown and Muhammad Abdullah. Cham: Palgrave Macmillan, pp. 257-83.

Abdel Haleem, Muhammad A. S. 2016. The Qur'an: A new translation by M.A.S Abdel Haleem. New York: Oxford University Press.

Ahmed, Asma. 2016. Exploring the Experiences of Muslim Students in an Urban Ontario Public School. London: The University of Western Ontario.

Alaboudi, Munirah. 2018. Islamic School Teachers' Perceptions on How They Seek to Affect Their Students' Ability to Live as Muslims in American Society. Boston: Boston University.

Al-Refai, Nader Sudqy. 2011. An Exploration of Islamic Studies Curriculum Models in Muslim Secondary Schools in England. Derby: University of Derby.

Bourke, Roseanna, and Judith Loveridge. 2016. Beyond the official language of learning: Teachers engaging with student voice research. Teaching and Teacher Education 57: 59. [CrossRef]

Buckingham, Jennifer. 2010. ABC Religion \& Ethics. ABC 1: 10. Available online: https://www.abc.net.au/religion/ the-rise-of-religious-schools-in-australia/10102062 (accessed on 22 June 2020).

Clauss, Kathryn, Shamshad Ahmed, and Mary Salvaterra. 2013. The rise of Islamic schools in the United States. The Innovation Journal 18. Available online: http://innovation.cc/scholarly-style/2013_18_1_12_clauss_ahmed_ islamic-school.pdf (accessed on 23 June 2020).

Cook-Sather, Alison. 2006. Sound, presence, and power: "Student Voice" in educational research and reform. Curriculum Inquiry 36: 359. [CrossRef]

Devers, Kelly J., and Richard M. Frankel. 2000. Study design in qualitative research-2: Sampling and data collection strategies. Education for Health Change in Learning and Practice 13: 263-71. [CrossRef]

Diallo, Ibrahima, and Lockyer Kerrilee. 2016. The Role and Importance of Islamic Studies and Faith in Community Islamic Schools in Australia A Case Study of Adelaide (SA) and Darwin (NT). Adelaide: University of South Australia Research Centre for Languages and Cultures, Available online: https://apo.org.au/sites/default/ files/resource-files/2016-11/apo-nid70627.pdf (accessed on 23 June 2020).

Douglass, Susan L., and Munir A. Shaikh. 2004. Defining Islamic education: Differentiation and applications. Current Issues in Comparative Education 7. Available online: https://www.tc.columbia.edu/cice/pdf/25707_7_1_ Douglas_Shaikh.pdf (accessed on 23 June 2020).

Eddles-Hirsch, Katrina. 2015. Phenomenology and Educational Research. International Journal of Advanced Research (IJAR) 3: 251-60. Available online: http://www.journalijar.com/uploads/287_IJAR-6671.pdf (accessed on 24 June 2020).

Etikan, Ilker, Sulaiman Abubakar Musa, and Rukayya Sunusi Alkassim. 2016. Comparison of convenience sampling and purposive sampling. American Journal of Theoretical and Applied Statistics 5: 1-4. [CrossRef]

Fielding, Michael. 2004. Transformative approaches to student voice: Theoretical underpinnings, recalcitrant realities. British Educational Research Journal 30: 295-311. [CrossRef]

Friend, Jennifer, and Loyce Caruthers. 2015. Transforming the School Reform Agenda: A framework for including student voice in urban school renewal. Journal of Urban Learning Teaching and Research 11: 14-25. Available online: https://files.eric.ed.gov/fulltext/EJ1071419.pdf (accessed on 24 June 2020). 
Halliday, Amber J., Margaret L. Kern, David K. Garrett, and Deborah A. Turnbul. 2019. The student voice in well-being: A case study of participatory action research in positive education. Educational Action Research (Routledge) 27: 173-96. [CrossRef]

Hussain, Serena, and Jen'nan Ghazal Read. 2015. Islamic schools in the United States and England: Implications for integration and social cohesion. Social Compass, 556-69. [CrossRef]

Independent Schools Council of Australia. 2019. Independent Schools Council of Australia. Available online: https://isca.edu.au/about-independent-schools/about-independent-schools/autonomy-andaccountability/ (accessed on 22 June 2020).

McCreery, Elaine, Liz Jones, and Rachel Holmes. 2007. Why do Muslim parents want Muslim schools? Early Years 27: 203-19. [CrossRef]

McDonough, Graham P., Nadeem A. Memon, and Avi I. Mintz. 2013. Discipline, Devotion, and Dissent Jewish, Catholic, and Islamic Schooling in Canada. Waterloo: Wilfrid Laurier University Press.

Memon, Nadeem A. 2016. Diverse communities, divergent aspirations? Islamic schooling in the west. In Philosophies of Islamic Education Historical Perspectives and Emerging Discourses. Edited by Nadeem A. Memon and Mujadad Zaman. Routledge: London, UK, pp. 145-58.

Memon, Nadeem A., and Mariam Alhashmi. 2018. Islamic Pedagogy: Potential and Perspective. In Islamic Schooling in the West Pathways to Renewal. Edited by Mohamad Abdalla, Dylan Chown and Muhammad Abdullah. Cham: Palgrave Macmillan, pp. 169-94.

Memon, Nadeem A., and Mujadad Zaman. 2016. Philosophies of Islamic Education Historical Perspectives and Emerging Discourses. London: Routledge.

Memon, Nadeem. 2011. What Islamic school teachers want: Towards developing an Islamic teacher education programme. British Journal of Religious Education 33: 285-98. [CrossRef]

Memon, Nadeem. 2012. From mosques to madrassas: Civic engagement and the pedagogy of Islamic schools. In Islam in the Hinterlands Muslim Cultural Politics in Canada. Edited by Jasmin Zine. Toronto: UBC Press, pp. 185-207.

Memon, Nadeem. 2019. A History of Islamic Schooling in North America Mapping Growth and Evolution. London, UK: Routledge.

Messiou, Kyriaki, and Mel Ainscow. 2015. Responding to learner diversity: Student views as a catalyst for powerful teacher development? Teaching and Teacher Education 51: 246-47. [CrossRef]

Sahih al-Bukhari. 2016. Book 74, Hadith 46. Available online: https://sunnah.com/bukhari/74/46 (accessed on 23 June 2020).

Shah, Saeeda. 2012. Muslim schools in secular societies: Persistence or resistance! British Journal of Religious Education 34: 51-65. [CrossRef]

Shakeel, M. Danish. 2018. Islamic schooling in the cultural west: A systematic review of the issues concerning school choice. Religions 9: 392. [CrossRef]

Sumner, Maggie. 2006. Qualitative research. In The SAGE Dictionary of Social Research Methods. Edited by Victor Jupp. New York: SAGE Publications, p. 249.

Swain, Katharine, Donna Pendergast, and Joy Cumming. 2018. Student experiences of NAPLAN: Sharing insights from two school sites. The Australian Educational Researcher 45: 315-42. [CrossRef]

Ucan, Ayse Demirel, and Andrew Wright. 2019. Improving the pedagogy of Islamic religious education through an application of critical religious education, variation theory and the learning study model. British Journal of Religious Education, 202-17, Available online. [CrossRef]

Woodward, Scott, Adam Lloyd, and Royce Kimmons. 2017. Student voice in textbook evaluation: Comparing open and restricted textbooks. International Review of Research in Open and Distributed Learning 18: 150-63. Available online: https:/files.eric.ed.gov/fulltext/EJ1155838.pdf (accessed on 24 June 2020). [CrossRef]

(C) 2020 by the authors. Licensee MDPI, Basel, Switzerland. This article is an open access article distributed under the terms and conditions of the Creative Commons Attribution (CC BY) license (http://creativecommons.org/licenses/by/4.0/). 